\title{
Accumulation of macronutrients in different parts of sunflower fertilized with cassava wastewater
}

\author{
Mara S. M. Dantas ${ }^{1}$, Mario M. Rolim ${ }^{1}$, Elvira M. R. Pedrosa ${ }^{1}$, \\ Egídio Bezerra Neto ${ }^{2}$, Gerônimo F. da Silva ${ }^{1} \&$ Ênio F. de F. e Silva ${ }^{1}$ \\ ${ }^{1}$ Universidade Federal Rural de Pernambuco/Departamento de Engenharia Agrícola. Recife,PE. E-mail: mara_suy@hotmail.com; mario.rolim@ufrpe.br \\ (Corresponding author); elvira.pedrosa@ufrpe.br; agrogefe@yahoo.com.br; effsilva@uol.com.br \\ ${ }^{2}$ Universidade Federal Rural de Pernambuco/Departamento de Química. Recife, PE. E-mail: egidio@dq.ufrpe.br
}

\section{Key words:}

Helianthus annuus

nutrition

fertilization

residue

Manihot esculenta

\begin{abstract}
A B S T R A C T
The utilization of organic wastes in agriculture is an alternative that can reduce the amounts of mineral fertilizers applied to the soil. The aim of this study was to evaluate the accumulation of macronutrients in sunflower cv. 'Hélio 250' fertilized with cassava wastewater. The experiment was conducted in randomized block design, with six treatments $(0 ; 8.5 ; 17$; 34; 68 and $136 \mathrm{~m}^{3} \mathrm{ha}^{-1}$ of cassava wastewater) and four replications. The accumulation of nitrogen $(\mathrm{N})$, phosphorus $(\mathrm{P})$, potassium $(\mathrm{K})$, calcium $(\mathrm{Ca})$, magnesium $(\mathrm{Mg})$ and sulfur $(\mathrm{S})$ were evaluated in leaves, stem, capitulum and achenes. The cassava wastewater dose of $136 \mathrm{~m}^{3} \mathrm{ha}^{-1}$ promoted the greatest accumulation of all evaluated nutrients. The pattern of macronutrients accumulation occurred in the following order: leaves - $\mathrm{Ca}>\mathrm{K}>\mathrm{N}>\mathrm{Mg}>$ $\mathrm{S}>\mathrm{P}$; stem - $\mathrm{K}>\mathrm{Ca}>\mathrm{Mg}>\mathrm{N}>\mathrm{P}>\mathrm{S}$; capitulum - $\mathrm{N}>\mathrm{K}>\mathrm{P}>\mathrm{Mg}>\mathrm{Ca}>\mathrm{S}$; and achenes - $\mathrm{N}>\mathrm{P}>\mathrm{K}>\mathrm{Mg}>\mathrm{S}>\mathrm{Ca}$. The extraction of nutrients by whole sunflower plants occurred in the following order: $\mathrm{N}>\mathrm{K}>\mathrm{Ca}>\mathrm{Mg}>\mathrm{P}>\mathrm{S}$. Cassava wastewater provided appropriate concentrations of $\mathrm{N}, \mathrm{P}, \mathrm{K}, \mathrm{Ca}, \mathrm{Mg}$ and $\mathrm{S}$; therefore, it has potential as an organic fertilizer for the studied sunflower cultivar.
\end{abstract}

\section{Palavras-chave:}

Helianthus annuus nutrição

adubação

resíduo

Manihot esculenta

\section{Acúmulo de macronutrientes em distintas partes de girassol adubado com manipueira}

\begin{abstract}
R E S U M O
A utilização de resíduos orgânicos em cultivos é uma alternativa capaz de reduzir quantidades de adubos minerais aplicados ao solo. Objetivou-se, com este trabalho, avaliar o acúmulo de macronutrientes na cultura do girassol cultivar Hélio 250 adubado com manipueira. $\mathrm{O}$ delineamento experimental foi em blocos ao acaso, com seis tratamentos $(0 ; 8,5 ; 17 ; 34$; 68 e $136 \mathrm{~m}^{3} \mathrm{ha}^{-1}$ de manipueira) em quatro repetições. Foram avaliados os acúmulos de nitrogênio $(\mathrm{N})$, fósforo $(\mathrm{P})$, potássio $(\mathrm{K})$, cálcio $(\mathrm{Ca})$, magnésio $(\mathrm{Mg})$ e enxofre $(\mathrm{S})$ nas folhas, caules, capítulos e aquênios. A dose de $136 \mathrm{~m}^{3}$ ha-1 de manipueira foi a que proporcionou o maior acúmulo para todos os nutrientes avaliados. $\mathrm{O}$ acúmulo dos macronutrientes ocorre na seguinte ordem por órgão: folhas $\mathrm{Ca}>\mathrm{K}>\mathrm{N}>\mathrm{Mg}>\mathrm{S}>\mathrm{P}$; caule $\mathrm{K}>\mathrm{Ca}>\mathrm{Mg}>\mathrm{N}>$ $\mathrm{P}>\mathrm{S}$; capítulos $\mathrm{N}>\mathrm{K}>\mathrm{P}>\mathrm{Mg}>\mathrm{Ca}>\mathrm{S}$; aquênios $\mathrm{N}>\mathrm{P}>\mathrm{K}>\mathrm{Mg}>\mathrm{S}>\mathrm{Ca}$. A ordem de acumulação dos nutrientes pelas plantas inteiras de girassol é: $\mathrm{N}>\mathrm{K}>\mathrm{Ca}>\mathrm{Mg}>\mathrm{P}>\mathrm{S}$. A manipueira, por ter fornecido concentrações suficientes de $\mathrm{N}, \mathrm{P}, \mathrm{K}, \mathrm{Ca}, \mathrm{Mg}$ e S, apresenta potencial, como fertilizante orgânico para a cultivar estudada do girassol.
\end{abstract}




\section{INTRODUCTION}

Cassava wastewater, a residue generated in the processing of cassava to make flour, has chemical composition with great potential to be used as a fertilizer, for its high contents of $\mathrm{N}$ (3064.0 mg L $\mathrm{m}^{-1}$ ), P (312.0 $\left.\mathrm{mg} \mathrm{L}^{-1}\right), \mathrm{K}\left(3200.0 \mathrm{mg} \mathrm{L}^{-1}\right)$, Ca (241.9 $\mathrm{mg} \mathrm{L}^{-1}$ ) and $\mathrm{Mg}$ (1588.2 $\mathrm{mg} \mathrm{L}^{-1}$ ) (Dantas et al., 2015) and lower contents of micronutrients. Thus, its utilization as organic fertilizer turns the residue into a low-cost profitable product, reducing environmental impacts and increasing crop yield (Cardoso et al., 2009).

Crop management using agro-industrial residues has proven to be a sustainable alternative from the social, environmental and economic perspective, since these residues have in their composition large amounts of nutrients, which, when incorporated to the soil, can increase agricultural yield through the improvement in soil fertility (Modesto et al., 2009).

Therefore, evaluations of chemical composition and accumulation of nutrients in the various plant organs provide important information for the understanding on the nutritional demands of the crops, since such information can be later used as a reference to calculate the dose of nutrients to be supplied to plants through fertilization (Laviola \& Dias, 2008).

Among the studied alternatives for cassava wastewater, its use as a fertilizer becomes an economically viable option for farmers, generating increase in crop yield and economy with mineral fertilizers. Studies have demonstrated the beneficial effects of cassava wastewater when used in agriculture as a fertilizer on the development and yield of crops, as reported by Cardoso et al. (2009), Cabral et al. (2010), Santos et al. (2010), Araújo et al. (2012) and Duarte et al. (2012).

Given the above, this study aimed to evaluate the accumulation of macronutrients in sunflower, cv. 'Hélio 250', fertilized with cassava wastewater.

\section{Material ANd Methods}

The experiment was carried out from October 2012 to January 2013 in the municipality of Vitória de Santo Antão-PE, Brazil ( $8^{\circ} 8^{\prime} 0^{\prime \prime} \mathrm{S} ; 35^{\circ} 22^{\prime} 0^{\prime \prime} \mathrm{W}$ ). The climate in the region is C1S2 A' a', according to Köppen's classification. The soil in the area is a dystrophic Red Yellow Latosol and its physical and chemical characteristics, in the layer of 0-0.4 m, are shown in Table 1 .

The experimental design was randomized blocks, with six treatments represented by six doses of cassava wastewater $(0$, $8.5,17,34,68$ and $\left.136 \mathrm{~m}^{3} \mathrm{ha}^{-1}\right)$ and four replicates. The applied doses of cassava wastewater corresponded to $0,25,50,100,200$ and $400 \mathrm{~kg} \mathrm{ha}^{-1}$ of potassium (K), respectively.

The recommended dose to be applied in the soil was calculated based on the $\mathrm{K}$ content of the residue, since it is the element in highest concentration in its composition, following the recommendation of Ribeiro et al. (1999), considering the dose of $8.5 \mathrm{~m}^{3} \mathrm{ha}^{-1}$ as the amount of $\mathrm{K}$ required by the crop under the local conditions, which corresponds to $25 \mathrm{~kg} \mathrm{ha}^{-1}$ of $\mathrm{K}$. The other doses were calculated based on the recommended dose, through its multiplication by two, four, eight and sixteen.

Each experimental unit consisted of four 6-m-long rows at spacing of 1.0 between rows and $0.20 \mathrm{~m}$ between plants, in a total of 120 plants per plot, which is equivalent to a density of 50,000 plants ha ${ }^{-1}$. The evaluated area of each plot $\left(10.4 \mathrm{~m}^{2}\right)$ corresponded to 52 plants located in the two central rows. For this, two plants were disregarded at each end during the harvest.

The physico-chemical composition of the cassava wastewater was determined using the methodology of APHA (1995) and the results are shown in Table 2.

Soil preparation consisted of plowing, harrowing and furrowing in rows spaced by $1.0 \mathrm{~m}$ at the depth of $0.30 \mathrm{~m}$. Irrigation was performed using a 16-mm flexible drip tape, with emitters spaced by $0.2 \mathrm{~m}$ and flow rate of $1.0 \mathrm{~L} \mathrm{~h}^{-1}$. Irrigation depths were determined based on crop evapotranspiration (ETc), while reference evapotranspiration (ETo) was estimated through the Hargreaves-Samani method, using the crop coefficients $(\mathrm{Kc})$ recommended for sunflower. During all the cycle, an irrigation depth of $357 \mathrm{~mm}$ was applied.

Cassava wastewater doses were applied at once in 0.08-m-deep furrows, 15 days before planting. The sunflower cultivar 'Hélio 250' was used in the experiment and sowing was performed directly at the field, by placing five seeds in each hole and leaving one plant per hole after thinning. Harvest was performed 90 days after sowing (DAS), when all sunflower capitula were facing down.

For the analysis of concentration of nutrients, two plants were sampled in each plot, 90 DAS. The plants were cut close to the soil surface and divided into leaves, stem, capitulum and achenes. After that, they were placed in paper bags and dried in a forced-air oven at $65^{\circ} \mathrm{C} . \mathrm{P}, \mathrm{K}, \mathrm{Ca}, \mathrm{Mg}$ and $\mathrm{S}$ were determined through nitric-perchloric aid digestion and $\mathrm{N}$ through sulfuric acid digestion (Bezerra Neto \& Barreto, 2011). The accumulation of nutrients was determined through the multiplication of the concentration of the nutrient by the dry mass corresponding to each plant part.

The data were subjected to analysis of variance by F test $(p \leq 0.05)$. When significant effect was observed,

Table 1. Physical and chemical characteristics of soil before cassava wastewater application

\begin{tabular}{|c|c|c|c|c|c|c|c|c|c|c|c|c|}
\hline Sand & Silt & Clay & \multirow{2}{*}{$\begin{array}{c}\mathrm{pH} \\
\left(1: 2.5 \mathrm{H}_{2} \mathrm{O}\right)\end{array}$} & \multirow{2}{*}{$\begin{array}{c}E^{E C^{*}} \\
d S m^{-1}\end{array}$} & \multirow{2}{*}{$\begin{array}{c}P \\
\mathrm{mg} \mathrm{dm^{-3 }}\end{array}$} & $\overline{K^{+}}$ & $\mathrm{Ca}^{2+}$ & $\mathrm{Mg}^{2+}$ & $\mathrm{Na}^{+}$ & $\mathrm{Al}^{3+}$ & $\mathrm{H}^{+}+\mathrm{Al}^{3+}$ & \multirow{2}{*}{$\begin{array}{c}\mathrm{OC}^{*} \\
\mathrm{~g} \mathrm{~kg}^{-1}\end{array}$} \\
\hline & $\mathrm{g} \mathrm{kg}^{-1}$ & & & & & \multicolumn{6}{|c|}{$\mathrm{cmol}_{\mathrm{c}} \mathrm{dm}^{-3}$} & \\
\hline 578 & 122 & 300 & 6.60 & 0.55 & 7.47 & 0.45 & 2.7 & 2.8 & 0.27 & 0.00 & 2.93 & 28 \\
\hline
\end{tabular}

*Electrical conductivity; *Organic carbon

Table 2. Characterization of physico-chemical parameters of cassava wastewater

\begin{tabular}{|c|c|c|c|c|c|c|c|c|c|c|}
\hline \multirow{3}{*}{$\begin{array}{c}\mathrm{COD}^{*} \\
\mathrm{mg} \mathrm{L}^{-1} \\
66.62\end{array}$} & \multirow{2}{*}{$\begin{array}{c}\text { EC } \\
\mathrm{dS} \mathrm{m}^{-1}\end{array}$} & \multirow{2}{*}{ pH } & $\mathbf{N}$ & $P$ & $\mathrm{~K}^{+}$ & $\mathrm{Ca}^{2+}$ & $\mathrm{Mg}^{2+}$ & $\mathrm{Na}^{+}$ & $\mathrm{SO}^{2-}$ & $\overline{\mathrm{Cl}^{-}}$ \\
\hline & & & \multicolumn{8}{|c|}{$\mathrm{mg} \mathrm{L}^{-1}$} \\
\hline & 7.27 & 6.60 & 3.064 .0 & 312.0 & 3.200 .0 & 241.9 & 1.588 .2 & 390.0 & 2.205 .0 & 795.0 \\
\hline
\end{tabular}

${ }^{*}$ Chemical oxygen demand 
regression analyses were performed and significant $(\mathrm{p} \leq 0.05)$ mathematical models were selected based on the highest coefficient of determination.

\section{Results AND Discussion}

$\mathrm{N}$ accumulation in sunflower leaves, stem, capitulum and achenes increased linearly as a function of the applied doses of cassava wastewater (Figures 1A, B, C and D).

In the absence of cassava wastewater (dose of $0 \mathrm{~m}^{3} \mathrm{ha}^{-1}$ ), the leaves accumulated $0.248 \mathrm{~g} \mathrm{plant}^{-1}$ and, at the highest dose $\left(136 \mathrm{~m}^{3} \mathrm{ha}^{-1}\right)$, the accumulation was equal to $1.349 \mathrm{~g} \mathrm{plant}^{-1}$, which is equivalent to an increment of $442 \%$ in $\mathrm{N}$ availability. Data are consistent with Fia et al. (2006), who evaluated the yield and concentration of nutrients of maize fertilized with increasing doses of sewage sludge and observed that $\mathrm{N}$ concentrations increased with the increment in the dose of the residue applied to the soil.

As to $\mathrm{N}$ accumulation in the sunflower stem, the maximum and minimum values estimated by the regression equations were 0.075 and $0.362 \mathrm{~g} \mathrm{plant}^{-1}$, obtained at the cassava wastewater doses of 0 and $136 \mathrm{~m}^{3} \mathrm{ha}^{-1}$, respectively. In the capitulum, $\mathrm{N}$ accumulation showed similar trend to that in the stem, accumulating $0.799 \mathrm{~g} \mathrm{plant}^{-1}$ at the dose of $0 \mathrm{~m}^{3} \mathrm{ha}^{-1}$ and $4.073 \mathrm{~g} \mathrm{plant}^{-1}$ at the dose of $136 \mathrm{~m}^{3} \mathrm{ha}^{-1}$, which corresponded to an increment of $410 \%$. In the achenes, $\mathrm{N}$ accumulation was $1.425 \mathrm{~g} \mathrm{plant}^{-1}$ at the dose of $0 \mathrm{~m}^{3} \mathrm{ha}^{-1}$ and $2.844 \mathrm{~g} \mathrm{plant}^{-1}$ at the dose of $136 \mathrm{~m}^{3} \mathrm{ha}^{-1}$, corresponding to an increment of $100 \%$. Similar results were reported by Lobo et al. (2013), who observed linear increase in $\mathrm{N}$ concentration in sunflower achenes as the applied $\mathrm{N}$ doses increased.

In the whole plant, the highest $\mathrm{N}$ accumulations at each dose and the sum of leaves, stem, capitulum and achenes were $2.547,2.926,3.306,4.066,5.585$ and 8.624 g plant $^{-1}$, for the doses of $0,8.5,17,34,68$ and $136 \mathrm{~m}^{3} \mathrm{ha}^{-1}$, respectively, which corresponded to extractions of 127, 146, 165, 203, 279 and 431 $\mathrm{kg} \mathrm{ha}^{-1}$ of $\mathrm{N}$. In sunflower organs, $\mathrm{N}$ extraction sequence was the following: capitulum $>$ achenes $>$ leaves $>$ stem. Comparatively, $\mathrm{N}$ extraction values surpassed those found by Zobiole et al. (2010), who observed maximum $\mathrm{N}$ accumulation, considering the sum of leaves, petioles, stem, capitulum and achenes, of $3.751 \mathrm{~g} \mathrm{plant}^{-1}$, at 85 days, corresponding to the extraction of $150 \mathrm{~kg} \mathrm{ha}^{-1}$ of N. N contents determined in the leaves indicate sufficient levels to plants, because they did not show symptoms of deficiency.

A similar response to that of $\mathrm{N}$ was observed for $\mathrm{P}$ accumulation in leaves, stem, capitulum and achenes of sunflower plants at the end of the crop cycle (Figures 1E, $1 \mathrm{~F}, 1 \mathrm{G}$ and $1 \mathrm{H})$. In the leaves, $\mathrm{P}$ accumulations of 0.051 and 0.237 g plant $^{-1}$ were observed at the cassava wastewater doses of 0 and $136 \mathrm{~m}^{3} \mathrm{ha}^{-1}$. P accumulation in the stem showed the same tendency, with 0.0711 and $0.264 \mathrm{~g} \mathrm{plant}^{-1}$ for the doses of 0 and $136 \mathrm{~m}^{3} \mathrm{ha}^{-1}$, respectively. Likewise, $\mathrm{P}$ accumulation in the capitulum was equal to $0.289 \mathrm{~g} \mathrm{plant}^{-1}$ in the absence of cassava wastewater $\left(0 \mathrm{~m}^{3} \mathrm{ha}^{-1}\right)$ and to $1.4189 \mathrm{~g} \mathrm{plant}^{-1}$ at the highest dose $\left(136 \mathrm{~m}^{3} \mathrm{ha}^{-1}\right)$, which represented an increase of $390.3 \%$. The same tendency occurred for $\mathrm{P}$ accumulation in the achenes, equal to $0.455 \mathrm{~g} \mathrm{plant}^{-1}$ at the dose of $0 \mathrm{~m}^{3} \mathrm{ha}^{-1}$ and $0.958 \mathrm{~g} \mathrm{plant}^{-1}$ at the dose of $136 \mathrm{~m}^{3} \mathrm{ha}^{-1}$.
The total P accumulations considering the sum of leaves, stem, capitulum and achenes were $0.867,0.990,1.113,1.359$, 1.851 and 2.878 g plant $^{-1}$ for the doses of $0,8.5,17,34,68$ and $136 \mathrm{~m}^{3} \mathrm{ha}^{-1}$, respectively, which were equivalent to extractions of $49.5,55.7,67.9,92.5$ and $143.9 \mathrm{~kg} \mathrm{ha}^{-1}$ of P. These results differ from those reported by Zobiole et al. (2010), who observed maximum $\mathrm{P}$ accumulation of $0.605 \mathrm{~g} \mathrm{plant}^{-1}$, considering the sum of leaves, petioles, stem, capitulum and achenes, corresponding to an extraction of $24 \mathrm{~kg} \mathrm{ha}^{-1}$ of $\mathrm{P}$, which remained below the results found in the present study. The order of P extraction by the organs was: capitulum $>$ achenes $>$ stem $>$ leaves.

The K contents accumulated in the whole sunflower plant increased linearly at rates of $0.087,0.0124,0.01$ and $0.0025 \mathrm{~g}$ plant $^{-1}$, as a function of the increment in the applied doses of cassava wastewater (Figures 1I, 1J, 1L and 1M). The highest $\mathrm{K}$ accumulation in the leaves was equal to $1.522 \mathrm{~g} \mathrm{plant}^{-1}$ at the dose of $136 \mathrm{~m}^{3} \mathrm{ha}^{-1}$, while the lowest was $0.334 \mathrm{~g} \mathrm{plant}^{-1}$, at the dose of $0 \mathrm{~m}^{3} \mathrm{ha}^{-1}$. As to the $\mathrm{K}$ accumulation in the stem, the mean estimated values of 0.567 and $2.253 \mathrm{~g} \mathrm{plant}^{-1}$ were obtained at the cassava wastewater doses of 0 and $136 \mathrm{~m}^{3} \mathrm{ha}^{-1}$, respectively, which are equivalent to extractions of 28.4 and $112.6 \mathrm{~kg} \mathrm{ha}^{-1}$ of K, representing an increment of $297 \%$.

For $\mathrm{K}$ accumulation in the capitulum, the lowest value $\left(1.189 \mathrm{~g} \mathrm{plant}^{-1}\right)$ was obtained in the absence of cassava wastewater $\left(0 \mathrm{~m}^{3} \mathrm{ha}^{-1}\right)$, while the application of the highest dose $\left(136 \mathrm{~m}^{3} \mathrm{ha}^{-1}\right)$ promoted the highest accumulation $(2.548$ g plant ${ }^{-1}$ ), representing an increment on the order of $89.4 \%$, with extractions of 59.4 and $127.4 \mathrm{~kg} \mathrm{ha}^{-1}$ of $\mathrm{K}$, respectively. In the achenes, $\mathrm{K}$ accumulation followed the same tendency, with $0.377 \mathrm{~g} \mathrm{plant}^{-1}$ at the lowest dose and $0.711 \mathrm{~g} \mathrm{plant}^{-1}$ at the highest dose, corresponding to extractions of 18.8 and $35.5 \mathrm{~kg} \mathrm{ha}^{-1}$ of $\mathrm{K}$.

In all plant organs, the total accumulations of $2.467,2.752$, $3.038,3.609,4.751$ and 7.034 g plant $^{-1}$, respectively, at the cassava wastewater doses of $0,8.5,17,34,68$ and $136 \mathrm{~m}^{3} \mathrm{ha}^{-1}$, corresponded to extractions of $123.3,137.6,151.9,180.4,237.5$ and $351.7 \mathrm{~kg} \mathrm{ha}^{-1}$. The order of Kextraction for the organs was: capitulum $>$ stem $>$ leaves $>$ achenes. According to Castro et al. (2006), sunflower is very demanding in $\mathrm{K}$, approximately $171 \mathrm{~kg}$ of $\mathrm{K}_{2} \mathrm{O}$ in the shoots (stem, petiole, leaf, capitulum and grains) for every ton of grains produced.

Castro \& Oliveira (2005) observed that the total extractions of $\mathrm{N}, \mathrm{P}$ and $\mathrm{K}$ in the shoots, for a production of $3,176 \mathrm{~kg}$ of achenes ha ${ }^{-1}$, were $130 \mathrm{~kg} \mathrm{ha}^{-1}$ of N, $25 \mathrm{~kg} \mathrm{ha}^{-1}$ of $\mathrm{P}$ and $400 \mathrm{~kg}$ $\mathrm{ha}^{-1}$ of K. In the present study, the extractions of N, P and K, considering the shoots for a production of $4.498 \mathrm{~kg}$ of achenes $\mathrm{ha}^{-1}$, at the highest dose of cassava wastewater $\left(136 \mathrm{~m}^{3} \mathrm{ha}^{-1}\right)$, were 431,144 and $341 \mathrm{~kg} \mathrm{ha}^{-1}$, respectively.

The increment in cassava wastewater doses promoted linear increase in Ca contents in leaves, stem, capitulum and achenes (Figure 2A, B, C and D). The contents accumulated in the leaves of plants without $\left(0 \mathrm{~m}^{3} \mathrm{ha}^{-1}\right)$ and with the highest dose (136 $\mathrm{m}^{3} \mathrm{ha}^{-1}$ ) of cassava wastewater increased from 0.658 to $2.244 \mathrm{~g}$ plant $^{-1}$, representing an increment of $241 \%$. Ca accumulation in the stem followed the same tendency, with 0.134 and $0.504 \mathrm{~g}$ plant ${ }^{-1}$ for the doses of 0 and $136 \mathrm{~m}^{3} \mathrm{ha}^{-1}$ of cassava wastewater, respectively, corresponding to an increment of $277 \%$. In the 
A.

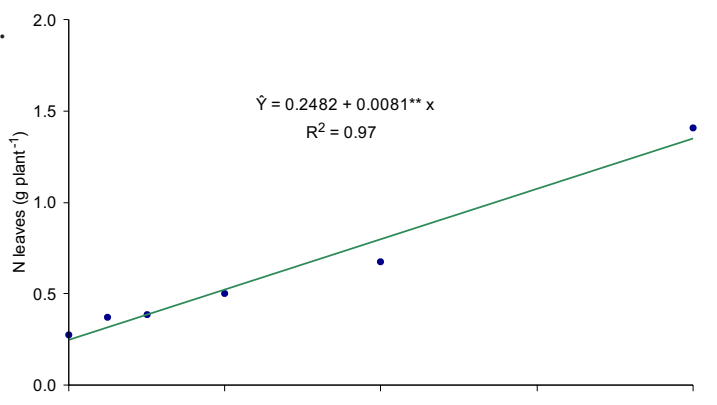

C.

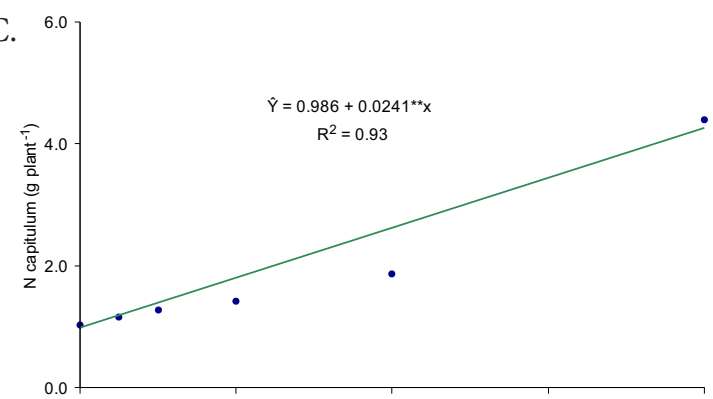

E.

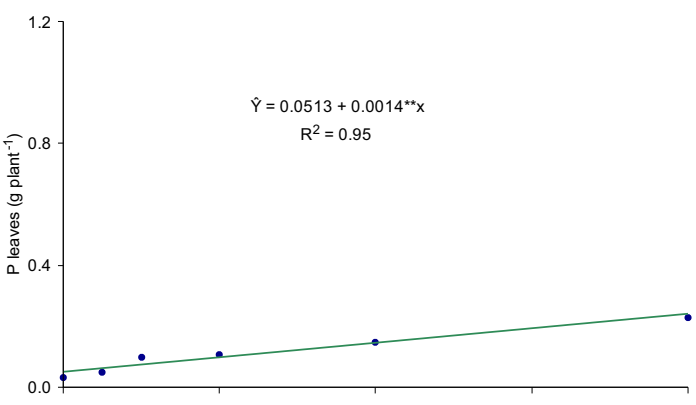

G.

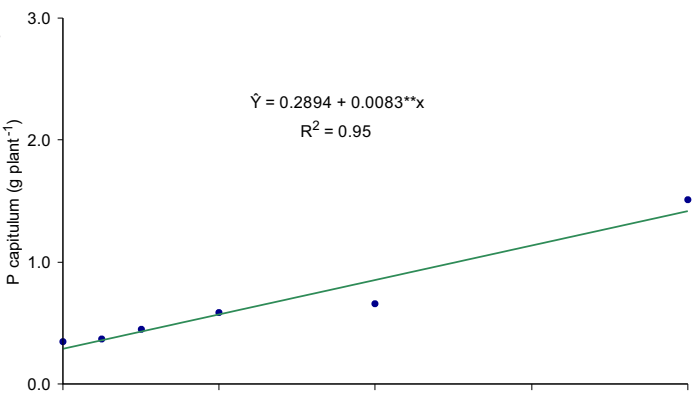

I.

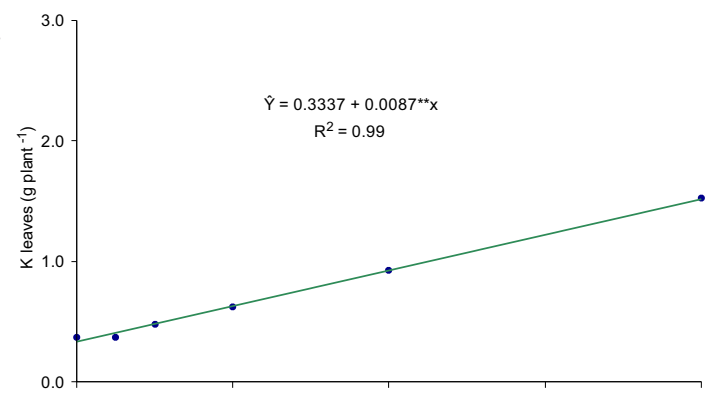

L.

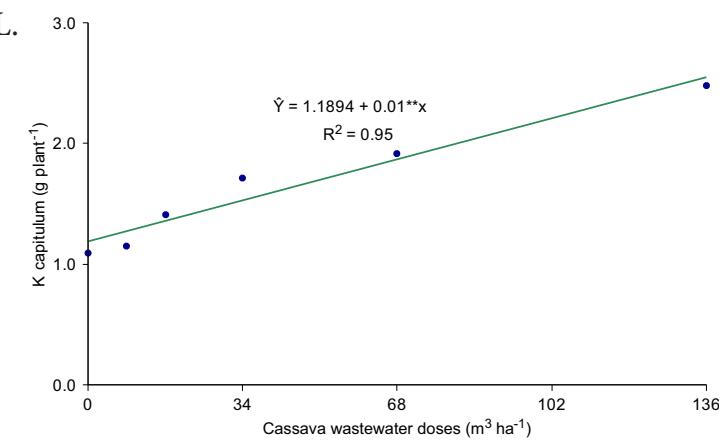

B.

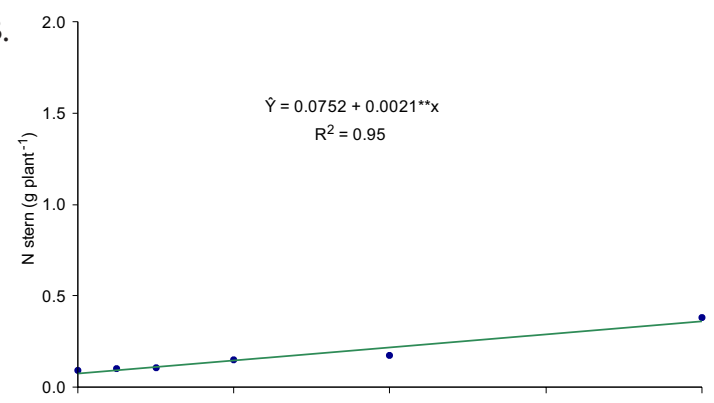

D.

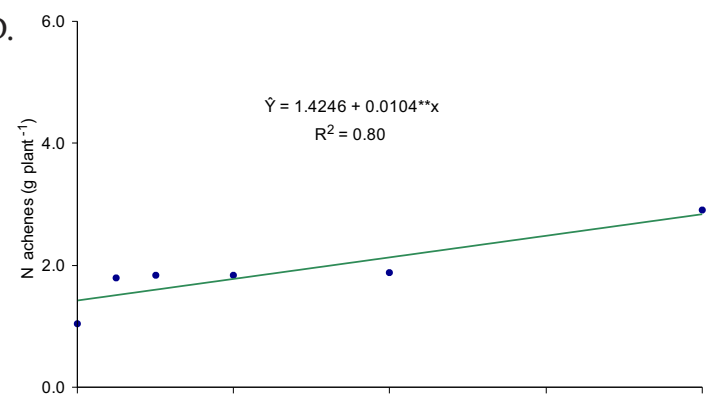

F.

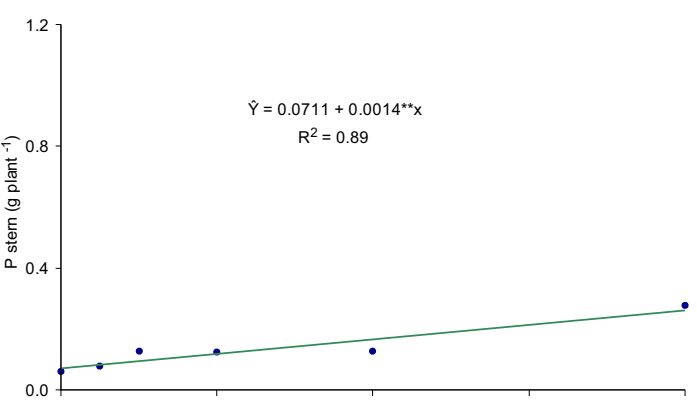

н
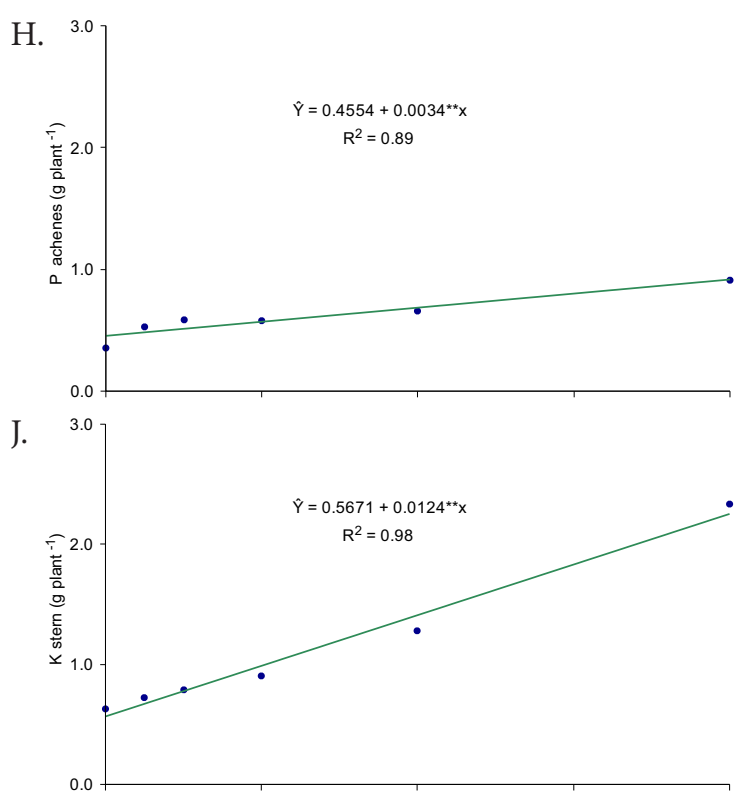

M.

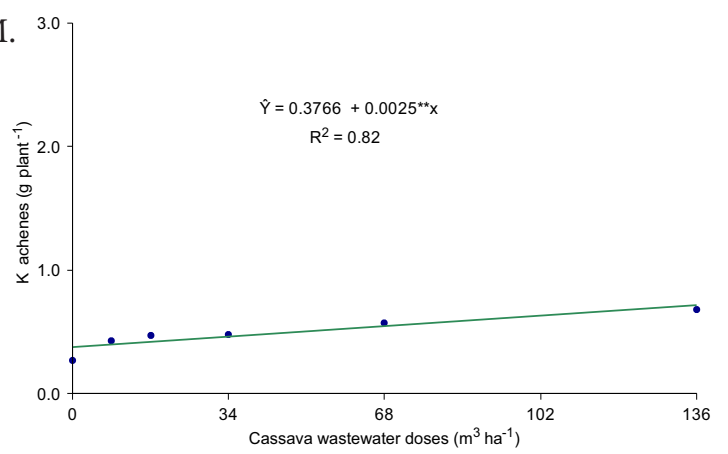

* significant at 0.05 probability level $(p<0.05)$; ** significant at 0.01 probability level $(p<0.01)$; ${ }^{\text {ns not significant }}$

Figure 1. Accumulation of nitrogen $(\mathrm{N})$, phosphorus $(\mathrm{P})$ and potassium $(\mathrm{K})$ in leaves, stem, capitulum and achenes of sunflower fertilized with different cassava wastewater doses 

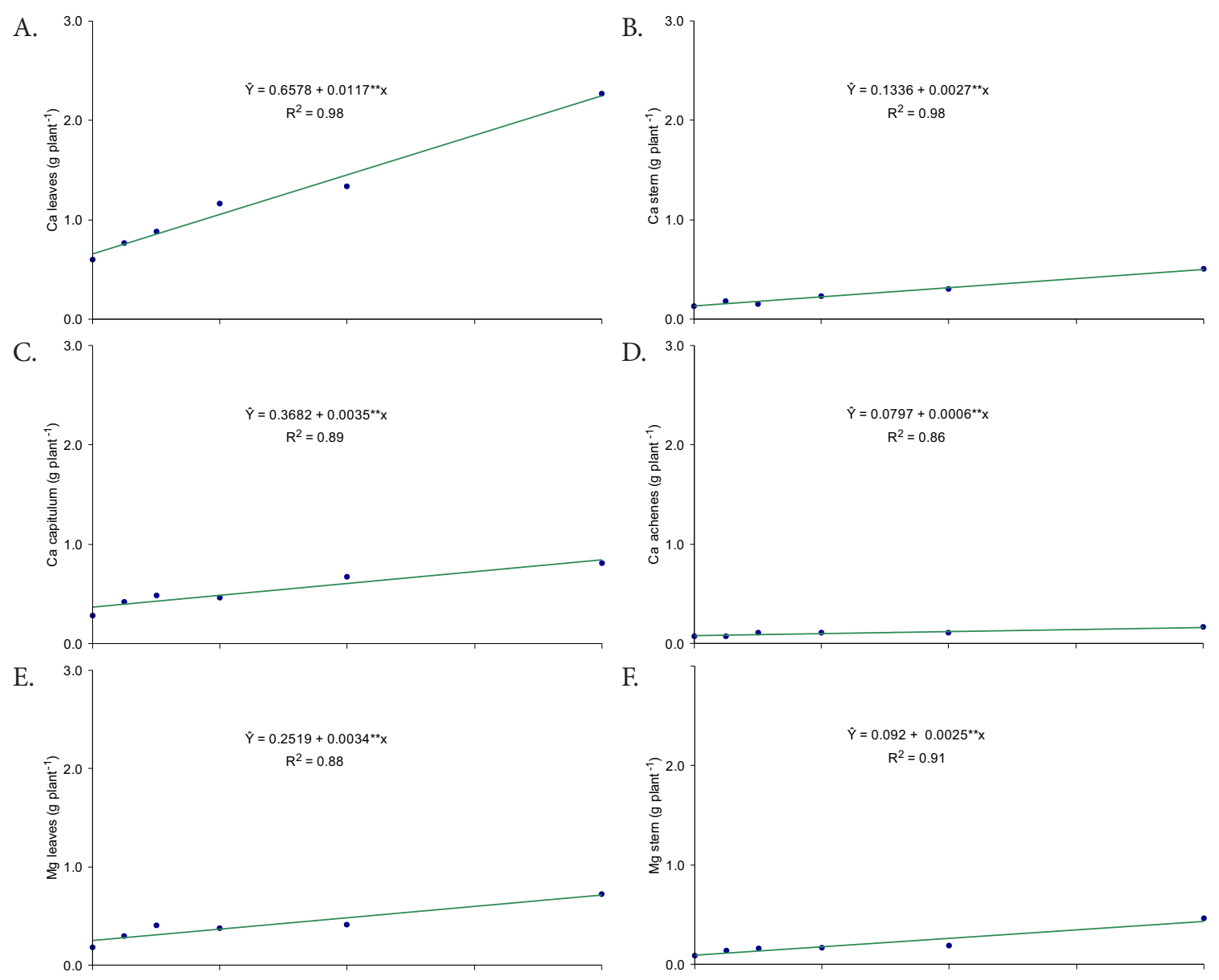

G.
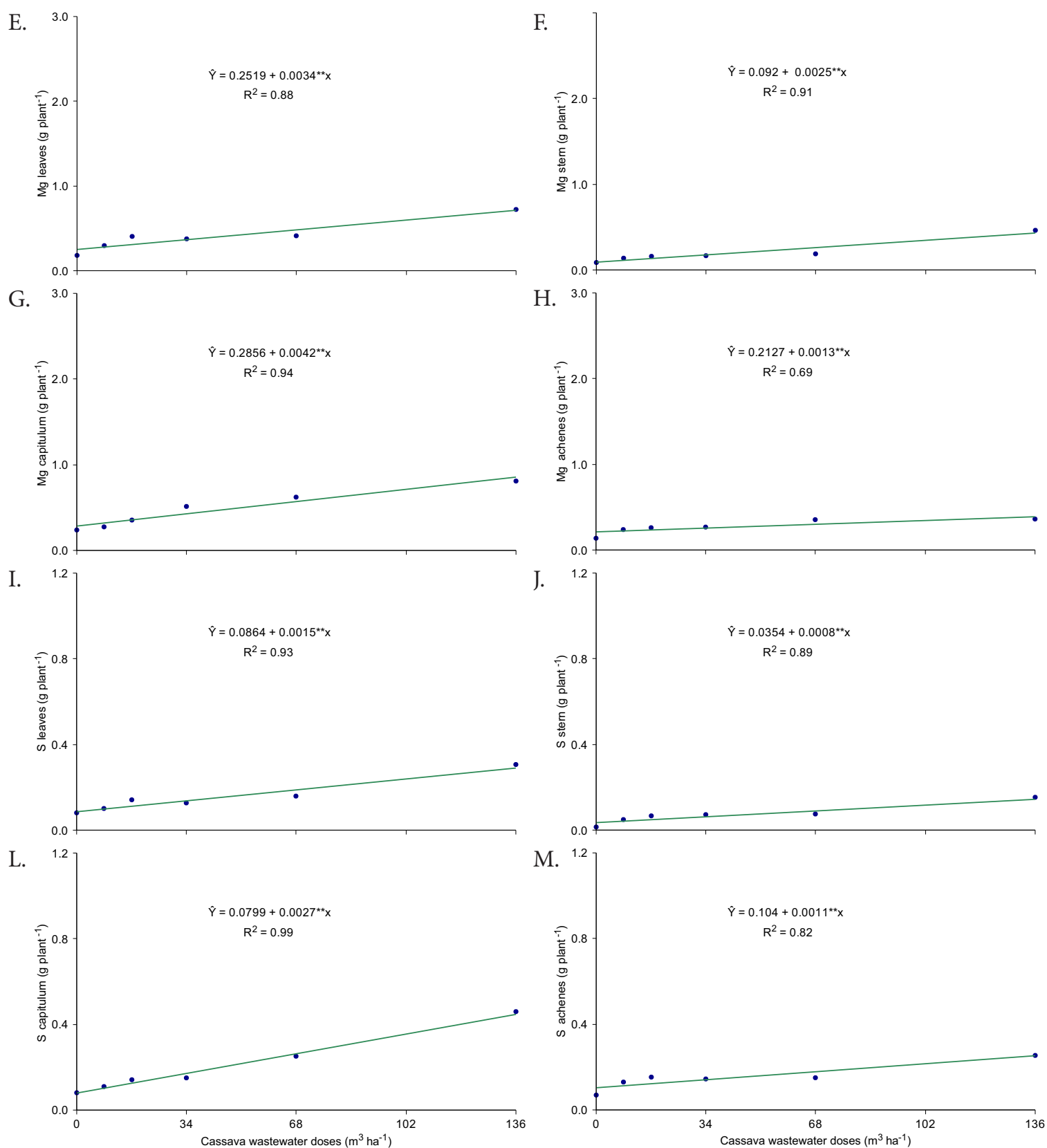

Figure 2. Accumulation of calcium (Ca), magnesium $(\mathrm{Mg})$ and sulfur $(\mathrm{S})$ in leaves, stem, capitulum and achenes of sunflower fertilized with different cassava wastewater doses 
capitulum, Ca accumulation was equal to $0.368 \mathrm{~g} \mathrm{plant}^{-1}$ at the dose of $0 \mathrm{~m}^{3} \mathrm{ha}^{-1}$ and $0.846 \mathrm{~g} \mathrm{plant}^{-1}$ at the dose of 136 $\mathrm{m}^{3} \mathrm{ha}^{-1}$, representing an increment of $130 \%$ from the lowest to the highest dose.

As to the accumulation of $\mathrm{Ca}$ in the achenes, the behavior was similar to that in leaves, stem and capitulum, as a function of the applied doses of cassava wastewater, with 0.079 and 0.163 g plant $^{-1}$ for the dose of 0 and $136 \mathrm{~m}^{3} \mathrm{ha}^{-1}$ of the organic input applied to the soil in liquid form. The total $\mathrm{Ca}$ accumulations in the whole plant were 1.239, 1.397, 1.554, 1.859, 2.497 and 3.757 g plant $^{-1}$, respectively, for the doses of $0,8.5,17,34,68$ and $136 \mathrm{~m}^{3} \mathrm{ha}^{-1}$, and corresponded to extractions of 61.97 , $69.84,77.71,92.94,124.85$ and $187.87 \mathrm{~kg} \mathrm{ha}^{-1}$, according to the following order of extraction per organ: leaves $>$ capitulum $>$ stem $>$ achenes. Zobiole et al. (2010), at 82 days, observed Ca accumulation of $2.903 \mathrm{~g} \mathrm{plant}^{-1}$, with extraction of $116 \mathrm{~kg} \mathrm{ha}^{-1}$. These results are similar to those found in the present study for the cassava wastewater doses of 68 and $136 \mathrm{~m}^{3} \mathrm{ha}^{-1}$.

As observed for the other macronutrients, $\mathrm{Mg}$ accumulation in leaves, stem, capitulum and achenes increased linearly with the increment in the doses of cassava wastewater (Figure 2E, $2 \mathrm{~F}, 2 \mathrm{G}$ and $2 \mathrm{H}) . \mathrm{Mg}$ contents in the leaves increased from $0.252 \mathrm{~g} \mathrm{plant}^{-1}$, at the dose of $0 \mathrm{~m}^{3} \mathrm{ha}^{-1}$, to $0.709 \mathrm{~g} \mathrm{plant}^{-1}$, at the highest dose $\left(136 \mathrm{~m}^{3} \mathrm{ha}^{-1}\right)$. In the same treatments, $\mathrm{Mg}$ contents increased from 0.092 to $0.393 \mathrm{~g} \mathrm{plant}^{-1}$ in the stem, 0.286 to $0.855 \mathrm{~g} \mathrm{plant}^{-1}$ in the capitulum and 0.213 to $0.392 \mathrm{~g} \mathrm{plant}^{-1}$ in the achenes. These values express increments of $178.5,327.2$, 209.4 and $84 \%$, respectively, between plants treated without cassava wastewater and with the highest dose.

The total $\mathrm{Mg}$ accumulations were equal to $0.842,0.939$, $1.107,1.228,1.526$ and $2.348 \mathrm{~g} \mathrm{plant}^{-1}$, respectively for the cassava wastewater doses of $0,8.5,17,34,68$ and $136 \mathrm{~m}^{3} \mathrm{ha}^{-1}$, corresponding to extractions of 42.1, 46.9, 55.4, 61.4, 76.3 and $117.4 \mathrm{~kg} \mathrm{ha}^{-1}$, in the following order of extraction per organ: capitulum $>$ leaves $>$ stem $=$ achenes. In sunflower, Zobiole et al. (2010) observed Mg accumulation of 1.047 g plant $^{-1}$ at 82 days, which corresponded to an extraction of $42 \mathrm{~kg} \mathrm{ha}^{-1}$, but higher values of accumulation and extraction were observed for the cassava wastewater doses of 17, 34, 68 and $136 \mathrm{~m}^{3} \mathrm{ha}^{-1}$.

For $\mathrm{S}$ accumulation, there was an increasing linear effect for the leaves, stem, capitulum and achenes (Figure 2I, 2J, 2L and $2 \mathrm{M})$. S accumulation in the leaves was equal to $0.086 \mathrm{~g} \mathrm{plant}^{-1}$ at the cassava wastewater dose of $0 \mathrm{~m}^{3} \mathrm{ha}^{-1}$ and $0.293 \mathrm{~g} \mathrm{plant}^{-1}$ at the dose of $136 \mathrm{~m}^{3} \mathrm{ha}^{-1}$, which represents an increment of $240 \%$. In the stem, there were accumulations of $0.354 \mathrm{~g} \mathrm{plant}^{-1}$ at the dose of $0 \mathrm{~m}^{3} \mathrm{ha}^{-1}$ and $0.149 \mathrm{~g}$ plant $^{-1}$ at the dose of $136 \mathrm{~m}^{3}$ $\mathrm{ha}^{-1}$, which corresponded to an increment of $371 \%$ from the lowest to the highest dose. In the capitulum, $\mathrm{S}$ accumulation was $0.799 \mathrm{~g}$ plant $^{-1}$ at the dose of $0 \mathrm{~m}^{3} \mathrm{ha}^{-1}$ and $0.450 \mathrm{~g} \mathrm{plant}^{-1}$ at the dose of $136 \mathrm{~m}^{3} \mathrm{ha}^{-1}$, representing an increase of $464 \%$ of the highest dose in relation to the lowest one. In the achenes, $\mathrm{S}$ accumulation was $0.104 \mathrm{~g} \mathrm{plant}^{-1}$ at the lowest dose and 0.178 g plant $^{-1}$ at the highest one, with increment of $71 \%$.

The total accumulations in the plant were $0.305,0.358$, $0.410,0.515,0.725$ and 1.153 g plant $^{-1}$, respectively, for the cassava wastewater doses of $0,8.5,17,34,68$ and $136 \mathrm{~m}^{3} \mathrm{ha}^{-1}$, representing an increment of $277 \%$ of the highest dose $\left(136 \mathrm{~m}^{3}\right.$ $\left.\mathrm{ha}^{-1}\right)$ in relation to the lowest one $\left(0 \mathrm{~m}^{3} \mathrm{ha}^{-1}\right)$, with extractions of $15.3,17.9,20.5,25.7,36.2$ and $57.6 \mathrm{~kg} \mathrm{ha}^{-1}$, respectively. The extraction per organ occurred in the following sequence: capitulum $>$ leaves $>$ achenes $>$ stem. According to Zobiole et al. (2010), the maximum $S$ accumulation occurred at 82 days and was $0.605 \mathrm{~g} \mathrm{plant}^{-1}$, with extraction of $24 \mathrm{~kg} \mathrm{ha}^{-1}$. Higher values were observed in the present study for the cassava wastewater doses of 68 and $136 \mathrm{~m}^{3} \mathrm{ha}^{-1}$, with total S accumulations of 0.723 and 1.153 g plant $^{-1}$, at 90 days after sowing, and extractions of 36.2 and $57.6 \mathrm{~kg} \mathrm{ha}^{-1}$. Based on the accumulation of nutrients, the order of extraction per element was: nitrogen $>$ potassium $>$ calcium $>$ magnesium $>$ phosphorus $>$ sulfur.

\section{Conclusions}

1. The cassava wastewater dose of $136 \mathrm{~m}^{3} \mathrm{ha}^{-1}$ promotes the highest accumulation of all nutrients evaluated.

2. Cassava wastewater provides adequate contents of $\mathrm{N}, \mathrm{P}$, $\mathrm{K}, \mathrm{Ca}, \mathrm{Mg}$ and $\mathrm{S}$, showing potential as an organic fertilizer for sunflower, cv. 'Hélio 250'.

3. The accumulation of macronutrients in the different organs is in the following order: Leaves $-\mathrm{Ca}>\mathrm{K}>\mathrm{N}>\mathrm{Mg}>$ $\mathrm{S}>\mathrm{P}$; Stem - $\mathrm{K}>\mathrm{Ca}>\mathrm{Mg}>\mathrm{N}>\mathrm{P}>\mathrm{S}$; Capitulum - N $>\mathrm{K}>$ $\mathrm{P}>\mathrm{Mg}>\mathrm{Ca}>\mathrm{S}$; and Achenes $-\mathrm{N}>\mathrm{P}>\mathrm{K}>\mathrm{Mg}>\mathrm{S}>\mathrm{Ca}$. The order of extraction of nutrients by sunflower plants is: $\mathrm{N}>\mathrm{K}$ $>\mathrm{Ca}>\mathrm{Mg}>\mathrm{P}>\mathrm{S}$.

\section{Literature Cited}

APHA - American Public Health Association, AWWA - American Water Works Association, WPCF - Washington Press Club Foundation. Standard methods for the examination of water and wastewater. Washington: American Public Health Association, 17.ed. 1995. 2198p.

Araújo, N. C. de; Ferreira, T. C.; Oliveira, S. J. C.; Gonçalves, C. P.; de Araújo, F. de A. C. de. Avaliação do uso de efluente de casas de farinha como fertilizante foliar na cultura do milho (Zea mays L.). Revista Engenharia na Agricultura, v.20, p.340-349, 2012. http:// dx.doi.org/10.13083/1414-3984.v20n04a06

Bezerra Neto, E.; Barreto, L. P. Análises químicas e bioquímicas em plantas. Recife: UFRPE, 2011. 267p.

Cabral, J. R.; Freitas, P. S. L.; Bertonha, A.; Muniz, A. S. Effects of wastewater from cassava industry on soil chemistry and crop yield of lopsided oats (Avena strigosa Schreb). Brazilian Archives of Biology and Technology, v.53, p.19-26. 2010. http://dx.doi. org/10.1590/S1516-89132010000100003

Cardoso, E.; Cardoso, D.; Cristiano, M.; Silva, L. da; Back, A. J.; Bernadim, A. M.; Paula, M. M. da S. Use of Manihot esculenta, crantz processing residue as biofertilizer in corn crops. Research Journal of Agronomy, v.3, p.1-8, 2009.

Castro, C.; Oliveira, F. A. Nutrição e adubação do girassol. In: Girassol no Brasil. Londrina:, v.1, p.317-374, 2005.

Castro, C.; Oliveira, F. A.; Moreira, A.; Salinet, L. S.; Veronesi, C. O. Rochas brasileiras como fonte alternativa de potássio para a cultura do girassol. Espaço \& Geografia, v.9, p.179-193, 2006. 
Dantas, M. S. M.; Rolim, M. M.; Duarte, A. S.; Pedrosa, E. M. R.; Tabosa, J. N.; Dantas, D. C. Crescimento do girassol adubado com resíduo líquido do processamento de mandioca. Revista Brasileira de Engenharia Agrícola e Ambiental, v.19, p.350357, 2015. http://dx.doi.org/10.1590/1807-1929/agriambi. v19n4p350-357

Duarte, A. S.; Silva, E. F. F.; Rolim, M. M.; Ferreira, R. F. A. L.; Malheiros, S. M. M.; Albuquerque, F. S. Uso de diferentes doses de manipueira na cultura da alface em substituição à adubação mineral. Revista Brasileira de Engenharia Agrícola e Ambiental, v.16, p.262-267, 2012. http://dx.doi.org/10.1590/S141543662012000300005

Fia, R.; Matos, A. T.; Aguirre, C. I. Produtividade e concentração de nutrientes e metais pesados em milho adubado com doses crescentes de lodo de esgoto caleado. Engenharia na Agricultura, v.14, p.39-50, 2006.

Laviola, B. G.; Dias, L. A. S. Teor e acúmulo de nutrientes em folhas e frutos de pinhão-manso. Revista Brasileira de Ciências do Solo, v.32, p.1969-1975, 2008. http://dx.doi.org/10.1590/S010006832008000500018
Lobo, T. F.; Grassi Filho, H.; Bull, L. T.; Kummer, A. C. B. Efeito do lodo de esgoto e do nitrogênio nos fatores produtivos do girassol. Revista Brasileira de Engenharia Agrícola e Ambiental, v.17, p.504509, 2013. http://dx.doi.org/10.1590/S1415-43662013000500006

Modesto, P. T.; Scabora, M. H.; Colodro, G.; Maltoni, K. L.; Cassiolato, A. M. R. Alterações em algumas propriedades de um Latossolo degradado com uso de lodo de esgoto e resíduos orgânicos. Revista Brasileira de Ciência do Solo, v.33, p.1489-1498, 2009. http:// dx.doi.org/10.1590/S0100-06832009000500039

Ribeiro, A. C.; Guimarães, P. T. G.; Alvarez V., V. H. Recomendações para o uso de corretivos e fertilizantes em Minas Gerais. $5^{a}$ aproximação Viçosa: CFSEMG, 1999. 359p.

Santos, M. H. V.; Araújo, A C.; Santos, D. M. R.; Lima, N. S.; Lima, A. C. A.; Lima, C. L. C.; Santiago, A. D. Uso da manipueira como fonte de potássio na cultura da alface (Lactuca sativa L.) cultivada em casa de vegetação. Acta Scientiarum Agronomy, v.32, p.729-733, 2010.

Zobiole, L. H. S.; Castro, C.; Oliveira, F. A.; Oliveira Júnior, A.; Moreira, A. Curva de crescimento, estado nutricional, teor de óleo e produtividade do girassol híbrido BRS 191 cultivado no estado do Paraná. Revista Brasileira de Oleaginosas e Fibrosas, v.14, p.55-62, 2010. 